\title{
The effects of exercise and adipose tissue lipolysis on plasma adiponectin concentration and adiponectin receptor expression in human skeletal muscle
}

\author{
Chamindie Punyadeera ${ }^{1}$, Antoine H G Zorenc ${ }^{2}$, René Koopman ${ }^{2}$, Andrew J McAinch ${ }^{3}$, Egbert Smit ${ }^{2}$, \\ Ralph Manders ${ }^{2}$, Hans A Keizer ${ }^{4}$, David Cameron-Smith ${ }^{3}$ and Luc J C van Loon ${ }^{2,4}$ \\ ${ }^{1}$ Department of Pathology, Research Institute GROW, Maastricht University, Maastricht, The Netherlands, ${ }^{2}$ Department of Human Biology, Nutrition \\ Research Institute Maastricht (NUTRIM), Maastricht University, The Netherlands, ${ }^{3}$ School of Exercise and Nutrition Sciences, Deakin University, \\ Burwood, Victoria, Australia and ${ }^{4}$ Department of Movement Sciences, NUTRIM, Maastricht University, The Netherlands
}

(Correspondence should be addressed to L J C van Loon; Email: L.vanLoon@HB.unimaas.nl)

\begin{abstract}
Objective: It has been suggested that adiponectin regulates plasma free fatty acid (FFA) clearance by stimulating FFA uptake and/or oxidation in muscle. We aimed to determine changes in plasma adiponectin concentration and adiponectin receptor 1 and 2 mRNA expression in skeletal muscle during and after prolonged exercise under normal, fasting conditions (high FFA trial; HFA) and following pharmacological inhibition of adipose tissue lipolysis (low FFA trial; LFA). Furthermore, we aimed to detect and locate adiponectin in skeletal muscle tissue.

Methods: Ten subjects performed two exercise trials $\left(120 \mathrm{~min}\right.$ at $50 \% \mathrm{VO}_{2 \max }$ ). Indirect calorimetry was used to determine total fat oxidation rate. Plasma samples were collected at rest, during exercise and during post-exercise recovery to determine adiponectin, FFA and glycerol concentrations. Muscle biopsies were taken to determine adiponectin protein and adiponectin receptor 1 and 2 mRNA expression and to localise intramyocellular adiponectin.

Results: Basal plasma adiponectin concentrations averaged $6.57 \pm 0.7$ and $6.63 \pm 0.8 \mathrm{mg} / \mathrm{l}$ in the HFA and LFA trials respectively, and did not change significantly during or after exercise. In the LFA trial, plasma FFA concentrations and total fat oxidation rates were substantially reduced. However, plasma adiponectin and muscle adiponectin receptor 1 and 2 mRNA expression did not differ between trials. Immunohistochemical staining of muscle cross-sections showed the presence of adiponectin in the sarcolemma of individual muscle fibres and within the interfibrillar arterioles.

Conclusion: Plasma adiponectin concentrations and adiponectin receptor 1 and 2 mRNA expression in muscle are not acutely regulated by changes in adipose tissue lipolysis and/or plasma FFA concentrations. Adiponectin is abundantly expressed in muscle, and, for the first time, it has been shown to be present in/on the sarcolemma of individual muscle fibres.
\end{abstract}

European Journal of Endocrinology 152 427-436

\section{Introduction}

Adiponectin, also known as Acrp30 (1, 2), adipoQ (3), apM-1 (4) and GBP28 (5) is a circulating hormone secreted by adipose tissue. Correlation studies have demonstrated that reduced adiponectin expression and/or low plasma adiponectin concentrations are associated with obesity (6), insulin resistance (7) and/or coronary artery disease (8). Moreover, exogenous adiponectin administration has been shown to improve insulin sensitivity in obese diabetic (9) and adiponectin-knockout mice (10). Although the exact physiological function of adiponectin remains to be established, it has been suggested that adiponectin plays a regulatory role in substrate metabolism in liver (11) and skeletal muscle (2).
Both weight loss and exercise have proven effective in the prevention and treatment of arteriosclerosis and skeletal muscle insulin resistance $(12-14)$. Whereas weight loss and/or energy intake restriction have been associated with elevated plasma adiponectin concentrations $(7,8)$, studies investigating the effects of exercise on adiponectin release have provided inconsistent findings (15-22). Kraemer et al. (15) investigated the acute effects of short-term, running exercise on plasma adiponectin secretion in healthy subjects but observed no changes. Other studies, exploring the more long-term benefits of exercise training, also reported no changes in basal plasma adiponectin concentration $(16-18,22)$. In contrast, Kriketos et al. (19) recently reported substantially elevated fasting plasma adiponectin levels $(260 \%$ above baseline 
values) after $2-3$ bouts of low to moderate intensity exercise. Studies investigating the acute effects of prolonged, moderate intensity exercise are presently lacking. Therefore, the first aim of the present study was to determine plasma adiponectin concentrations during and after a single bout of prolonged, moderate intensity exercise in healthy, lean men.

In rodent studies, adiponectin has been reported to regulate plasma free fatty acid (FFA) clearance by stimulating skeletal muscle FFA uptake (10) and/or oxidation $(2,9)$. In line with these findings, it has been suggested that adiponectin release is acutely regulated by circulating plasma FFA concentrations (23, 24). Consequently, we speculated that pharmacological inhibition of adipose tissue lipolysis during and after exercise likely reduces plasma FFA availability and, as such, could prevent any exercise-induced changes in adiponectin release. As such, our second aim was to determine plasma adiponectin concentrations during and after prolonged exercise following administration of a nicotinic acid analogue.

Evidence to support the contention that adiponectin represents one of the hormones that mediate the crosstalk between adipose tissue and skeletal muscle is accumulating $(2,9,25,26)$. As such, it has been speculated that adiponectin must be located on the surface of and/or inside skeletal muscle fibres for signalling purposes. Therefore, our third aim was to determine the presence of adiponectin in human skeletal muscle tissue. Furthermore, we applied immunohistochemical staining on muscle cross-sections to localise intramuscular adiponectin. Furthermore, following the discovery of the adiponectin receptor 1 and $2(27)$, it has been suggested that the proposed effects of adiponectin on skeletal muscle metabolism might also be regulated at the receptor level. Therefore, our fourth aim was to measure adiponectin receptor 1 and 2 mRNA expression in skeletal muscle tissue obtained at rest, following exercise and after $2 \mathrm{~h}$ of subsequent recovery under normal, fasting conditions and following pharmacological inhibition of adipose tissue lipolysis.

\section{Materials and methods}

\section{Subjects}

Ten active male subjects (age: $23 \pm 1$ years; height: $1.82 \pm 0.03 \mathrm{~m}$; body weight: $74 \pm 3 \mathrm{~kg}$; body fat: $13.2 \pm 0.9 \%$; fat free mass: $64 \pm 3 \mathrm{~kg}$; maximal power output $\left(\mathrm{W}_{\max }\right)$ : $388 \pm 14 \mathrm{~W}$; oxygen uptake capacity $\left(\mathrm{VO}_{2 \max }\right): 62 \pm 3 \mathrm{ml} / \mathrm{kg}$ bodyweight $\left./ \mathrm{min}\right)$ were selected to participate in this study, which is part of a greater project investigating the metabolic consequences of reduced plasma FFA availability. Subjects were informed about the nature and risks of the experimental procedures before their written informed consent was obtained. This study was approved by the local Medical
Ethical Committee and performed according to the guidelines set by the Declaration of Helsinki.

\section{Pre-testing}

$\mathrm{W}_{\max }$ and $\mathrm{VO}_{2 \max }$ were measured on an electronically braked cycle ergometer (Lode Excalibur, Groningen, The Netherlands) during an incremental exhaustive exercise test one week before the first experimental trial (28). Body composition was assessed using the hydrostatic weighing method in the morning after an overnight fast. Simultaneously, residual lung volume was measured by the helium-dilution technique. Body fat percentage was calculated using Siri's equation (29). Fat free mass (FFM) was calculated by subtracting fat mass (FM) from total body weight.

\section{Diet and activity prior to testing}

All subjects maintained normal dietary and physical activity patterns throughout the experimental period. They refrained from heavy physical labour and exercise training for at least 3 days prior to each trial and filled out a food intake diary for 2 days prior to the first trial to keep dietary intake as identical as possible prior to the other trial. The evening before each trial, subjects received the same standardised meal $(41.2 \mathrm{~kJ} / \mathrm{kg}$ body weight; consisting of 72 energy \% (En\%) carbohydrate, $11 \mathrm{En} \%$ fat and $17 \mathrm{En} \%$ protein).

\section{Experimental trials}

Each subject performed two similar trials, separated by at least one week. Each trial consisted of 90 min of resting measurements, followed by 120 min of cycling exercise $\left(50 \% W_{\max }\right)$ and a $120 \mathrm{~min}$ recovery period. In both trials, blood samples were collected at regular time intervals. In addition, percutaneous muscle biopsies were taken from the vastus lateralis muscle before, immediately after and $2 \mathrm{~h}$ after exercise. In one trial (low FFA; LFA), adipose tissue lipolysis was inhibited by oral administration of a nicotinic acid analogue (500 mg Acipimox). In the other trial (high FFA; HFA), a placebo was administered. Both trials were performed in randomised order and executed in a double blind fashion.

\section{Protocol}

After an overnight fast, subjects arrived at the laboratory at $0800 \mathrm{~h}$ by car or public transportation. After 30 min of supine rest, a percutaneous muscle biopsy was taken from the vastus lateralis muscle. A Teflon catheter (Baxter, Utrecht, The Netherlands) was inserted into an antecubital vein for blood sampling, after which a resting blood sample was taken. At $\mathrm{t}=0$ and $\mathrm{t}=165 \mathrm{~min}$, a capsule containing $250 \mathrm{mg}$ Acipimox (Nedios, Byk, Zwanenburg, The Netherlands) 
or a placebo was orally administered. At $\mathrm{t}=90 \mathrm{~min}$ subjects started to exercise on a cycle ergometer at a workload of $50 \% \mathrm{~W}_{\max }$ for a $2-\mathrm{h}$ period. Whilst at rest, oxygen uptake $\left(\mathrm{VO}_{2}\right)$ and carbon dioxide excretion $\left(\mathrm{VCO}_{2}\right)$ were measured continuously (Oxycon- $\beta$, Mijnhart Bunnik, The Netherlands), during exercise, measurements were performed for 5 min every $15 \mathrm{~min}$ before blood collection. After cessation of exercise a second muscle biopsy was obtained, after which subjects rested supine for $2 \mathrm{~h}$ during which $\mathrm{VO}_{2}$ and $\mathrm{VCO}_{2}$ were again measured continuously. Blood samples for plasma FFA, glycerol, glucose, and adiponectin analyses were collected at $\mathrm{t}=0$ and $90 \mathrm{~min}$ (at rest), at $\mathrm{t}=120,150,180,210 \mathrm{~min}$ (exercise) and at $\mathrm{t}=240,300$ and $330 \mathrm{~min}$ (post-exercise recovery). After $2 \mathrm{~h}$ of recovery $(\mathrm{t}=330 \mathrm{~min})$ a third muscle biopsy was collected.

\section{Blood sample analysis}

Blood samples $(7 \mathrm{ml})$ were collected in EDTA-containing tubes and centrifuged at $1000 \times \boldsymbol{g}$ at $4^{\circ} \mathrm{C}$ for $10 \mathrm{~min}$. Plasma aliquots were frozen immediately in liquid nitrogen and stored at $-80{ }^{\circ} \mathrm{C}$ until analyses. Plasma glucose (Uni Kit III, Roche, Basel, Switzerland), FFA (NEFA-C, Wako Chemicals, Neuss, Germany), and free glycerol (148270, Roche, Indianapolis, IN, USA) concentrations were analysed with a COBAS FARA semiautomatic analyser (Roche). Plasma adiponectin concentrations were analysed by radioimmunoassay (Linco Diagnostics Inc., St Charles, MO, USA).

\section{Immunohistochemistry}

Muscle samples were dissected and frozen in liquid nitrogen. About $15 \mathrm{mg}$ muscle were frozen in nitrogen-cooled isopentane and embedded in Tissue-Tek (Sakura Finetek, Zoeterwoude, The Netherlands). Multiple serial sections $(5 \mu \mathrm{m})$ were thaw mounted on uncoated, pre-cleaned glass slides, fixated in formaldehyde and incubated overnight with an Acrp30/ adiponectin monoclonal antibody (MAB 10 651, R\&D Systems Inc, Minneapolis, MN, USA), and a laminin polyclonal antibody (Sigma Diagnostics, Steinheim, Germany). After washes with PBS, sections were incubated with appropriate conjugated secondary antibodies: GAMIgG2B Alexa555, GARIgGAlexa488 (Molecular Probes, Leiden, The Netherlands). Thereafter, sections were embedded in Mowiol-Tris (Calbiochem, Omnilabo, Etten-Leur, The Netherlands) containing $\quad 0.5 \mu \mathrm{g} / \mathrm{ml} \quad 4^{\prime}-6^{\prime}$-diamino-2-phenylindole (DAPI, Molecular Probes). Slides were examined using a Nikon E800 fluorescence microscope (Uvikon, Bunnik, The Netherlands) coupled to a Basler A113 C progressive scan colour charge-coupled device (CCD) camera. Appropriate controls, applying only primary or secondary antibodies, showed no signal.

\section{Immunoblotting}

About $30 \mathrm{mg}$ muscle tissue were sonificated in icecold buffer (20 mmol/l HEPES (pH 7.4), $100 \mathrm{mmol} / \mathrm{l}$ $\mathrm{KCl}, \quad 50 \mathrm{mmol} / \mathrm{l}$ beta-glycerophosphate, $50 \mathrm{mmol} / \mathrm{l}$ $\mathrm{NaF}, 1 \mathrm{mmol} / \mathrm{l}$ dithiothreitol, $0.5 \mathrm{mmol} / \mathrm{l} \quad \mathrm{Na}_{3} \mathrm{VO}_{4}$, $0.2 \mathrm{mmol} / \mathrm{l}$ EDTA, $2 \mathrm{mmol} / \mathrm{l} \mathrm{EGTA}, 0.1 \mathrm{mmol} / \mathrm{l} \mathrm{PMSF}$ and $1 \mathrm{mmol} / \mathrm{l}$ benzamidine). Homogenates were centrifuged for $5 \mathrm{~min}$ at $1000 \times \mathbf{g}$ and at $4^{\circ} \mathrm{C}$. Thereafter, the supernatant was centrifuged (at $10000 \times \boldsymbol{g}$ and at $4^{\circ} \mathrm{C}$ for $10 \mathrm{~min}$ ) and resolved in SDS-buffer. Human plasma was used as a positive control for adiponectin protein expression. First, albumin was filtered from the plasma sample, using the SwellGel Blue albumin removal kit (89 845, Pierce Biotechnology, Rockford, IL, USA). After boiling the samples, denatured protein from a subset of 20 plasma samples (each containing $\sim 6 \mu \mathrm{g}$ protein) and 10 different muscle samples (each containing $\sim 50 \mu \mathrm{g}$ protein) were run on $15 \%$ SDS-polyacrylamide gels and transferred onto $0.45 \mu \mathrm{m}$ nitrocellulose membranes. Membranes were exposed to a 1:1000 dilution of a monoclonal antihuman Acrp30/adiponectin antibody (MAB 10651) and incubated in a 1:10 000 dilution of horseradish peroxidase-conjugated antibody (Pierce). Light sensitive film (CL-Xposure; Pierce) was used to detect immunoreactive bands using chemiluminescent substrate (SuperSignal CL; Pierce).

\section{PCR methodology}

Total RNA was extracted from 10-15 mg wet muscle as previously described (30). cDNA was obtained using AMV Reverse Transcriptase and Oligo (dT)15 Primers (Promega, Madison, WI, USA). Samples were analysed in triplicate to detect adiponectin 1 and 2 receptor and cyclophilin mRNA transcripts using real time RT-PCR (Gene Amp 5700 sequence detection system, Applied Biosystems, Foster City, CA, USA) as previously described (30) using primer sequences obtained from GenBank (adiponectin receptor 1 NM_015999: forward primer, cgccatggagaagatggaa; reverse primer, tcatatgggatgacctccaa; adiponectin receptor 2 - NM_024551: forward primer, ggatccccgaacgcttttt; reverse primer, tgagacaccatggaagtgaacaa). A BLAST search confirmed homologous binding (31). Input cDNA concentrations were normalised for the housekeeping gene (cyclophilin-X52851: forward primer, catctgcactgccaagactga; reverse primer, ttcatgcettctttcactttgc).

\section{Calculations}

From respiratory measurements, total fat and carbohydrate oxidation rates were calculated using the 
non-protein respiratory quotient (32).

Fat oxidation rate $=1.695 \mathrm{VO}_{2}-1.701 \mathrm{VCO}_{2}$

Carbohydrate oxidation rate

$$
=4.585 \mathrm{VCO}_{2}-3.226 \mathrm{VO}_{2}
$$

with $\mathrm{VO}_{2}$ and $\mathrm{VCO}_{2}$ in $\mathrm{l} / \mathrm{min}$ and oxidation rates in $\mathrm{g} / \mathrm{min}$.

\section{Statistics}

All data are expressed as means \pm S.E.M. To compare substrate utilisation rates and plasma metabolite concentrations over time within a trial, a one-way repeated measures analysis of variance (ANOVA) was applied. To enable comparisons between trials, a two-way repeated measures ANOVA was applied. A Scheffé's post-hoc test was applied in case of a significant F-ratio to locate specific differences. For non-time-dependent variables, a Student's $t$-test for paired observations was used.

\section{Results}

\section{Plasma metabolites}

Plasma FFA concentrations increased substantially during exercise in the HFA trial $(P<0.001)$. During recovery, plasma FFA levels declined but remained well above pre-exercise resting levels $(P<0.001)$. In contrast, in the LFA trial, plasma FFA levels declined following Acipimox administration at rest, after which they remained below or at near baseline values throughout exercise and post-exercise recovery. Plasma FFA levels were significantly lower in the LFA versus the HFA trial $(P<0.001$; Fig. 1A). Plasma glycerol concentrations increased substantially during exercise in the HFA trial $(P<0.001)$. During recovery, plasma glycerol levels declined but remained well above pre-exercise resting values $(P<0.001)$. In the LFA trial, a small but significant increase in plasma glycerol was observed following the onset of exercise $(P<0.01)$. Thereafter, glycerol levels declined to preexercise resting values. Plasma glycerol levels were significantly lower in the LFA compared with the HFA trial $(P<0.001$; Fig. 1B). Plasma glucose concentrations declined during exercise in both trials $(P<0.001)$. During post-exercise recovery, plasma glucose levels remained below pre-exercise resting values. No significant differences in plasma glucose concentrations were observed between trials (Fig. 1C).

\section{Substrate utilisation}

Total fat and carbohydrate oxidation rates as well as total energy expenditure at rest, during exercise and during post-exercise recovery are provided in Table 1.

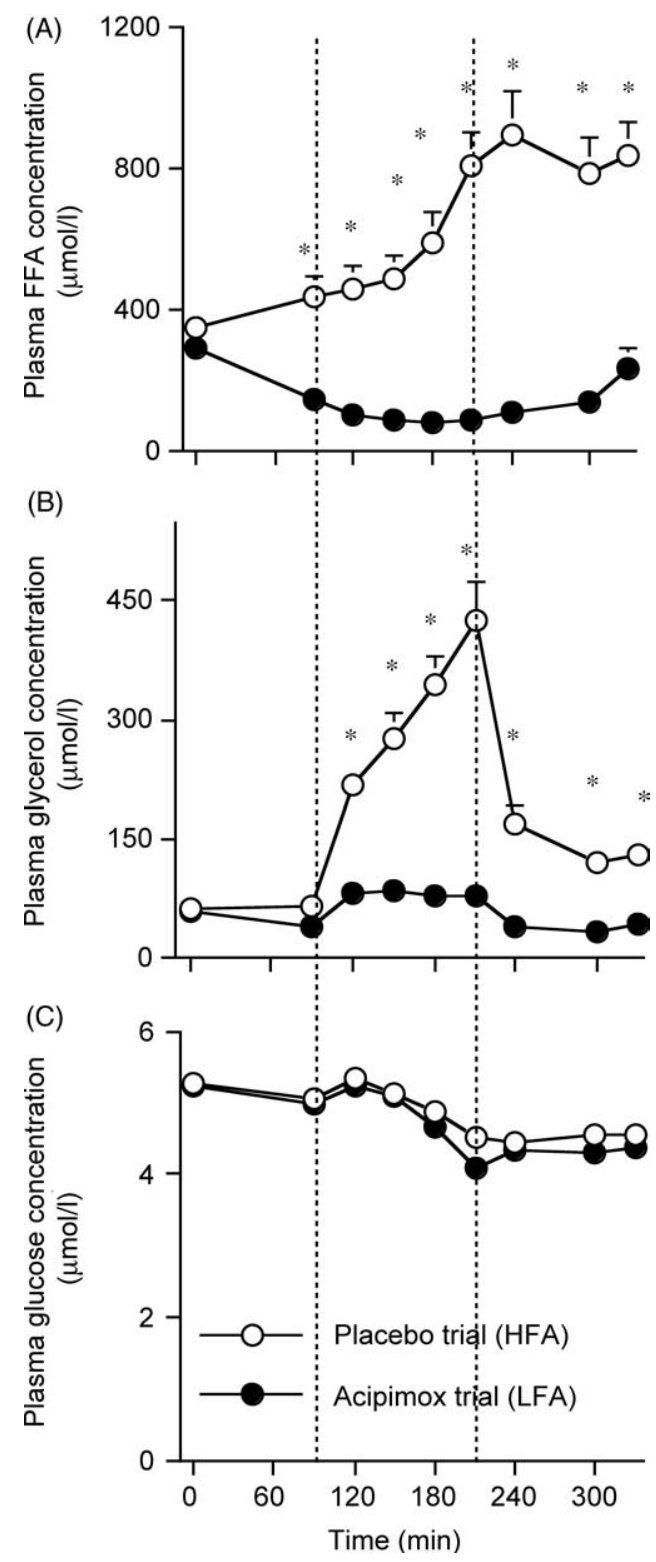

Figure 1 Plasma FFA (A), glycerol (B) and glucose (C) concentrations at rest, during prolonged submaximal exercise and during post-exercise recovery following administration of Acipimox (low FFA trial (LFA), solid circles) or a placebo (high FFA trial (HFA), open circles). Times for rest, exercise and post-exercise recovery are $t=0-90 \mathrm{~min}, t=90-210 \mathrm{~min}$ and $\mathrm{t}=210-330 \mathrm{~min}$, respectively. Data provided are means+S.E.M.; ${ }^{\star} P<0.05$, significant differences over time between trials in the resting, exercise and/or post-exercise recovery periods.

Total fat oxidation rates were substantially lower at rest, during exercise as well as during recovery in the LFA compared with the HFA trial $(P<0.05)$. Total carbohydrate oxidation rates were greater in the LFA trial when compared with the HFA trial. Energy expenditure at rest, during exercise and during subsequent recovery were similar between trials (Table 1 ). 
Table 1 Energy expenditure and substrate metabolism. Whole-body substrate oxidation following administration of a placebo (high FFA trial; HFA) or Acipimox (low FFA trial; LFA): total fat (FAT) oxidation rates, total carbohydrate (CHO) oxidation rates (expressed in $\mathrm{g} / \mathrm{min}$ ) and total energy expenditure (expressed in $\mathrm{kJ} / \mathrm{min}$ ) at rest. During exercise (at a $50 \% \mathrm{~W}_{\max }$ workload), and during 2 hours of post-exercise recovery. Data are expressed as means \pm S.E.M.

\begin{tabular}{|c|c|c|c|}
\hline & Rest & Exercise & Recovery \\
\hline \multicolumn{4}{|l|}{ Placebo trial (HFA) } \\
\hline FAT oxidation (g/min) & $0.087 \pm 0.007$ & $0.607 \pm 0.043$ & $0.112 \pm 0.008$ \\
\hline $\mathrm{CHO}$ oxidation (g/min) & $0.124 \pm 0.017$ & $1.984 \pm 0.130$ & $0.095 \pm 0.014$ \\
\hline Energy expenditure (kJ/min) & $5.54 \pm 0.23$ & $56.8 \pm 1.8$ & $6.08 \pm 0.30$ \\
\hline \multicolumn{4}{|l|}{ Acipimox trial (LFA) } \\
\hline FAT oxidation (g/min) & $0.069 \pm 0.007^{*}$ & $0.392 \pm 0.003^{*}$ & $0.070 \pm 0.008^{*}$ \\
\hline $\mathrm{CHO}$ oxidation (g/min) & $0.150 \pm 0.012^{*}$ & $2.535 \pm 0.102^{*}$ & $0.177 \pm 0.016^{*}$ \\
\hline Energy expenditure (kJ/min) & $5.26 \pm 0.24$ & $57.0 \pm 2.0$ & $5.69 \pm 0.24$ \\
\hline \multicolumn{4}{|l|}{ Ergometry } \\
\hline $50 \% \mathrm{~W}_{\max }$ workload (W) & & $194 \pm 7$ & \\
\hline Relative workload (\%VO $2 \max )$ & & $59.1 \pm 1.05$ & \\
\hline
\end{tabular}

* $P<0.05$ significantly different from HFA trial.

\section{Plasma adiponectin concentrations}

Fasting plasma adiponectin concentrations averaged $6.57 \pm 0.7$ and $6.63 \pm 0.8 \mathrm{mg} / \mathrm{l}$ before the HFA and LFA trials respectively (not significantly different). No significant changes in plasma adiponectin concentrations were observed over time in the LFA or HFA trial. No differences in circulating adiponectin were observed between trials $(P=0.989)$ (Fig. 2).

\section{Immunolocalisation}

Immunohistochemistry performed on skeletal muscle cross-sections showed adiponectin present in the sarcolemma of skeletal muscle fibres (Fig. 3A). As we applied an antilaminin antibody as a marker for the sarcolemmal and vascular walls (Fig. 3B), adiponectin is shown to be present on the sarcolemma of the individual

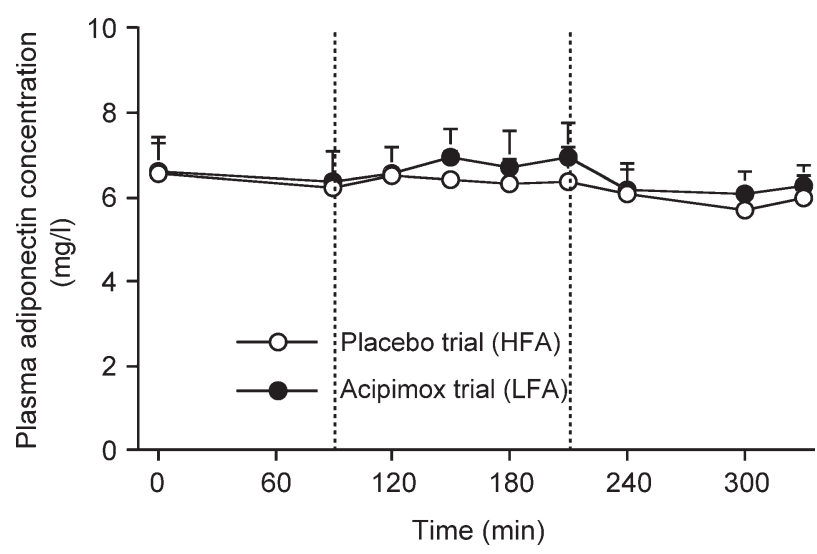

Figure 2 Plasma adiponectin concentrations at rest, during exercise and during recovery following administration of Acipimox (low FFA trial (LFA), solid circles) or a placebo (high FFA trial (HFA), open circles). Times for rest, exercise and post-exercise recovery are $\mathrm{t}=0-90 \mathrm{~min}, \mathrm{t}=90-210 \mathrm{~min}$ and $\mathrm{t}=210-330 \mathrm{~min}$, respectively. Data provided are means \pm S.E.M. There were no significant changes over time within the resting, exercise and/or post-exercise recovery periods in the LFA or HFA trial and there were no significant differences between trials $(P>0.05)$. muscle fibres as well as in/on the vascular endothelial lining of the interfibrillar arterioles (Fig. 3A). Adiponectin does not seem to be present in the cytosol nor does it seem to be associated with the muscle fibres' nuclei (Fig. 3C). These findings have been verified with two different anti-human adiponectin antibodies (MAB 10651 and AF1065; R\&D Systems, Inc.). No differences in adiponectin signal intensity or localisation were observed between biopsies collected before, immediately after or $2 \mathrm{~h}$ after exercise. No differences were observed between trials.

\section{Adiponectin protein expression}

Adiponectin protein expression in plasma and skeletal muscle tissue was visualised by Western blotting. Membranes probed with a primary monoclonal antibody (MAB 10 651) raised against an epitope in the globular domain (gAcrp30, amino acids 104244 ) of full-length adiponectin protein showed three bands at $\sim 28 \mathrm{kDa}$, $\sim 55 \mathrm{kDa}$ and $\sim 85 \mathrm{kDa}$ according to the molecular weight marker. These three bands likely correspond with the adiponectin monomeric $(1,5,33,34)$, dimeric $(2,5,34)$ and trimeric $(1,6,34)$ forms. The band observed between 28 and $34 \mathrm{kDa}$ likely represents one (or more) of the glycolysated isoforms (35). Whereas in plasma all three bands were shown, only the $\sim 28 \mathrm{kDa}$ and $\sim 85 \mathrm{kDa}$ bands were observed in muscle (Fig. 4). The blot depicted is representative for the muscle samples analysed.

\section{Adiponectin receptor 1 and 2 mRNA expression}

Skeletal muscle adiponectin receptor 1 and 2 mRNA content at rest, after exercise and after $2 \mathrm{~h}$ recovery are shown in Fig. 5A and B respectively. Adiponectin receptor 1 mRNA was more abundantly (25- to 70fold) expressed compared with receptor 2. Muscle mRNA contents are expressed relative to corresponding 

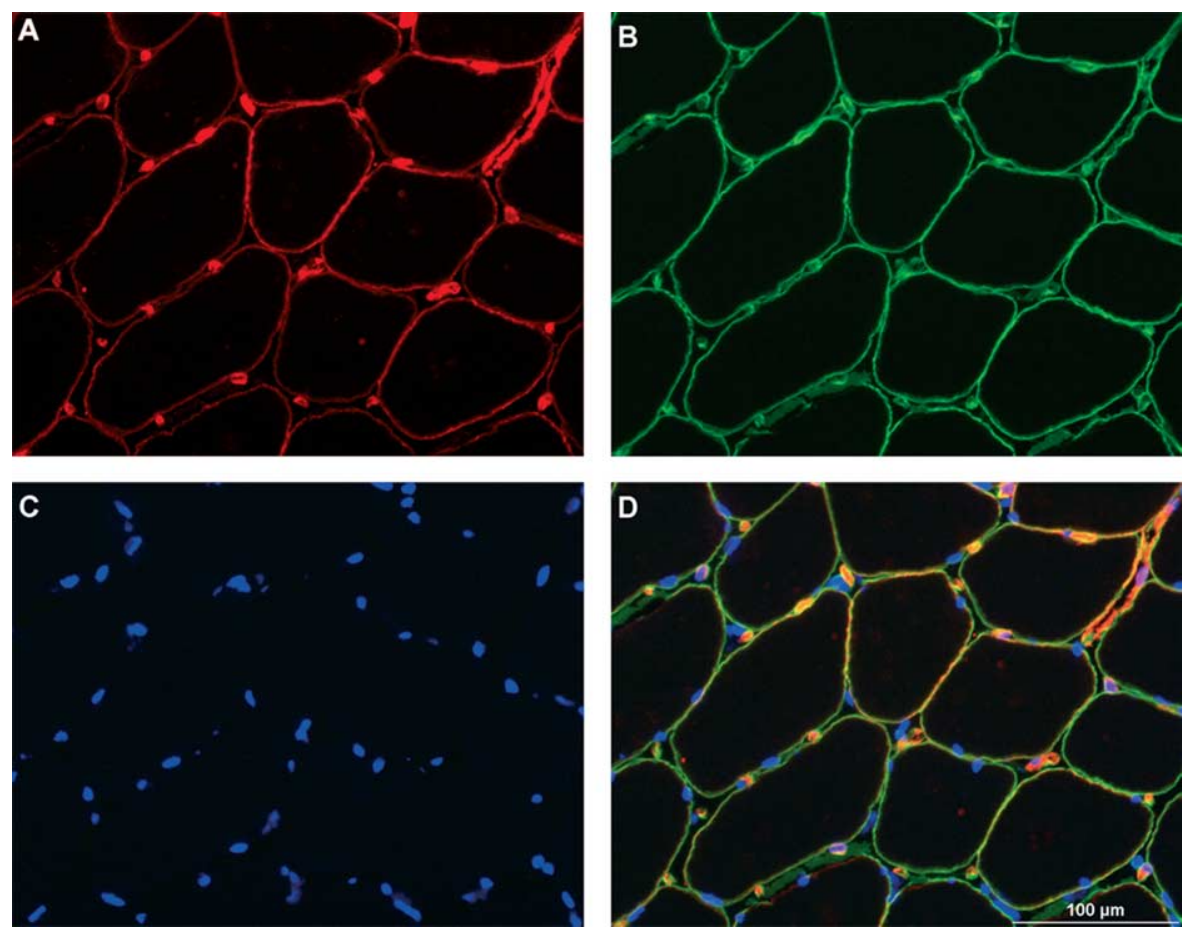

Figure 3 Digitally captured images of a single field-of-view (magnification $\times 240$ ) taken from a muscle cross-section obtained from a biopsy sample of the vastus lateralis. Images show the epifluorescence signal as recorded using a Texas red excitation filter for the adiponectin signal (showing adiponectin in red; A), an FITC excitation filter for laminin (showing cell membranes in green; B), and a DAPI UV excitation filter for myocellular nuclei (showing nuclei in blue; C). Section D shows the composite of all three signals.

baseline values, set to equal 1 . Adiponectin receptor 1 mRNA expression did not change with time in the HFA or LFA trial and did not significantly differ between groups $(P>0.05)$. Adiponectin receptor 2 mRNA

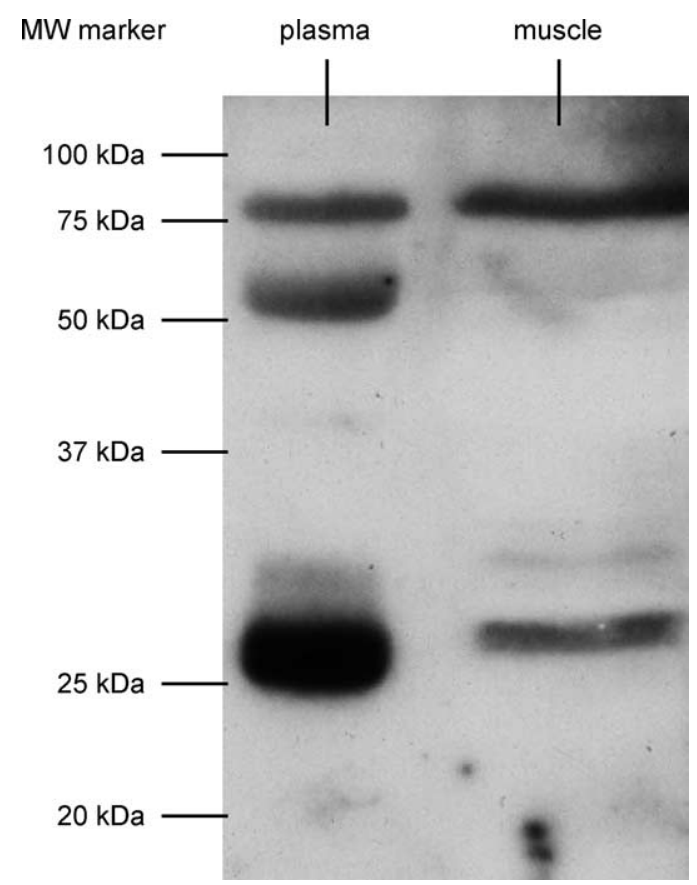

Figure 4 Representative blot showing adiponectin protein in human blood and mixed muscle homogenate. Membranes probed with a primary monoclonal antibody raised against the globular domain (gAcrp30, aa104-244) of the full-length adiponectin protein showing 3 bands at $\sim 28 \mathrm{kDa}, \sim 55 \mathrm{kDa}$ and $\sim 85 \mathrm{kDa}$ respectively. MW marker, molecular weight marker. content decreased significantly in the HFA trial only $(P=0.02)$. Differences in adiponectin receptor 2 mRNA content between trials did not reach statistical significance $(P=0.08)$.

\section{Discussion}

Since the discovery of the various adipocytokines, it has become apparent that adipose tissue is actively involved in the regulation of skeletal muscle metabolism. Recently, adiponectin has received much interest due to the observation that plasma adiponectin levels are reduced in the obese and/or type 2 diabetic state (3, $6-8,36-43)$. In line with these observations, dietary interventions $(8,20,44)$ as well as pharmacological treatment with thiazolidinediones $(34,45-50)$ to improve insulin sensitivity have been shown to elevate adiponectin concentrations. Although an acute bout of exercise and exercise training substantially improve insulin sensitivity $(13,14)$, their effect on plasma adiponectin remains to be elucidated $(15-22)$. In rodent studies, adiponectin has been shown to regulate plasma FFA clearance by stimulating skeletal muscle FFA uptake (10) and/or oxidation $(2,9)$. With adipose tissue lipolysis and plasma FFA appearance rates reaching maximal levels during prolonged, low to moderate intensity exercise $(51,52)$, we speculated that potential exercise-induced changes in plasma adiponectin concentration would be most prominent during or immediately after such exercise tasks. However, in accordance with earlier observations in athletes during short, highintensity running exercise (15), we did not observe any 

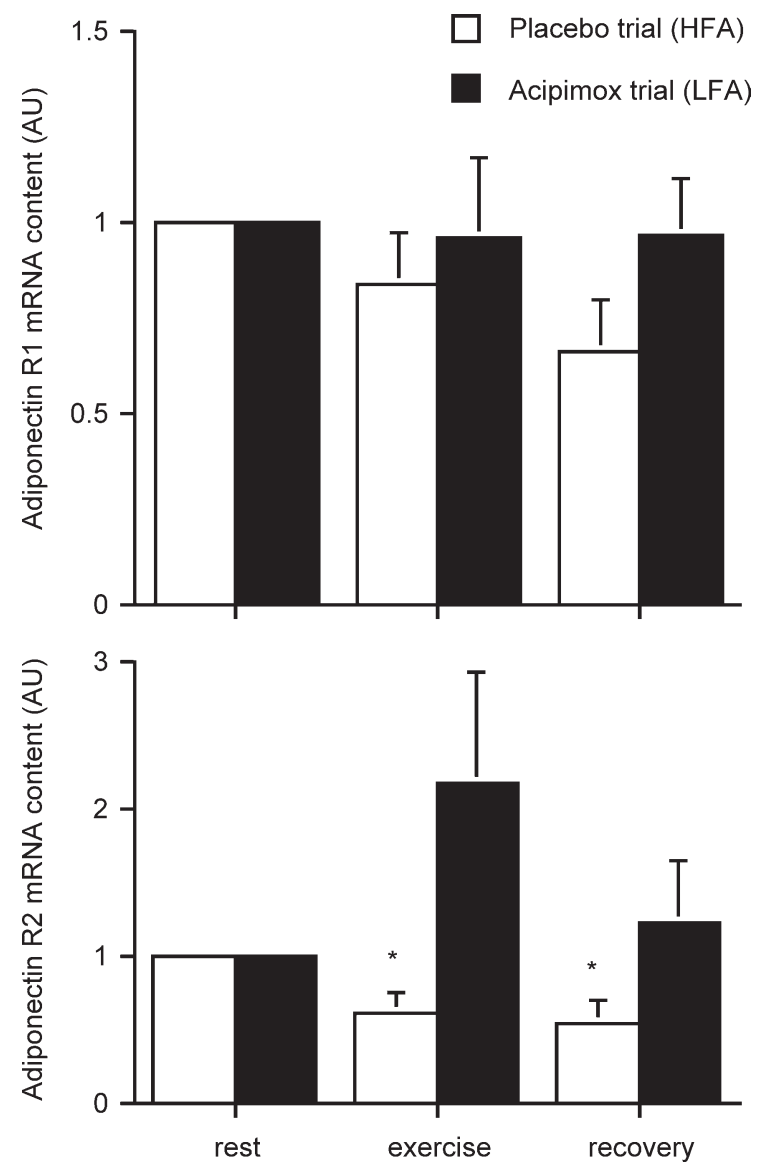

Figure 5 Adiponectin receptor 1 (A) and 2 (B) mRNA content in skeletal muscle tissue at rest, after exercise and during subsequent recovery following administration of Acipimox (low FFA trial (LFA), solid bars) or a placebo (high FFA trial (HFA), open bars). Gene expression was expressed relative to cyclophilin mRNA expression, with data normalised to resting values for each individual subject. ${ }^{\star} P<0.05$, significantly lower compared with resting values in the HFA trial. There were no significant differences between trials.

changes in plasma adiponectin concentration under exercise conditions. Even though adipose tissue lipolysis and fat oxidation rates were substantially elevated in the placebo trial (HFA; Table 1 and Fig. 1), plasma adiponectin concentrations remained unaffected during or after prolonged exercise (Fig. 2).

In accordance, studies exploring the benefits of participation in a long-term exercise training regimen generally report no changes in basal plasma adiponectin concentrations $(16-18,22)$. In contrast, Kriketos et al. (19) reported a massive increase in fasting plasma adiponectin levels after $2-3$ bouts of low to moderate intensity exercise performed within a oneweek period. Although it could be speculated that the inclusion of overweight, sedentary males in their study could be responsible for the apparent discrepant findings (19), others have failed to report such changes in a similar population after 6 months of exercise training (18). Therefore, further research is warranted to confirm the proposed effects of a short period of exercise training on plasma adiponectin levels. We conclude that adiponectin release is unrelated to the acute, temporary increase in adipose tissue lipolytic rate, plasma FFA concentration and/or whole-body fat oxidation rate during and immediately after prolonged, moderate intensity exercise in healthy, lean males.

Several groups have speculated on the proposed negative association between basal circulating adiponectin and plasma FFA and/or triglyceride concentrations $(7,53)$ and suggested that adiponectin release might be under acute negative feedback control by plasma FFA concentrations $(23,24)$. To investigate this, Staiger et al. (23) reduced plasma FFA availability in vivo in healthy males by administration of a nicotinic acid analogue (Acipimox) which specifically inhibits adipose tissue lipolysis $(54,55)$. The decline in plasma FFA levels observed in that study did not reduce plasma adiponectin concentrations (23). In contrast, Bernstein et al. (24) recently performed a similar study in which they reported a $\sim 40 \%$ decline in plasma adiponectin concentrations following Acipimox administration. In the present study, plasma FFA availability was reduced at rest, during exercise and during post-exercise recovery by Acipimox administration in the LFA trial. We observed a pronounced reduction in plasma FFA and glycerol concentrations (Fig. 1) and whole-body fat oxidation rates (Table 1). However, the latter did not affect plasma adiponectin concentrations (Fig. 2). Furthermore, no differences were observed between the HFA and LFA trials. In accordance with Staiger et al. (23), we conclude that adiponectin release is unrelated to an acute, temporary decline in adipose tissue lipolytic rate, plasma FFA concentration and/or whole-body fat oxidation rate in healthy, lean males. As such, our data imply that there are other, more important, factors that mediate adiponectin production and/or release by adipose tissue. The latter likely include adipocyte size and/or lipid content of the adipocyte, circulating catecholamines, glucocorticoids, tumour necrosis factor $\alpha$, and/or interleukin-6 (56). As animal work and human correlation studies still point towards an important regulatory role of circulating plasma adiponectin concentration on skeletal muscle metabolism (2), we speculated that adiponectin may be present in human skeletal muscle tissue. In accordance, Western blotting analyses showed adiponectin protein to be abundantly expressed in both plasma and skeletal muscle tissue (Fig. 4). Subsequently, we performed immunohistochemical staining on skeletal muscle cross-sections to show the presence of adiponectin on the sarcolemma of individual muscle fibres and within the endothelial lining of the interfibrillar arterioles (Fig. 3). The finding of adiponectin within the sarcolemma is surprising and has not been reported previously. The presence of adiponectin in the interfibrillar arterioles in human skeletal muscle tissue is consistent with the known actions of 
adiponectin as a potent anti-inflammatory and atheroprotective agent in vascular tissue (8, 57-59). Moreover, adiponectin has been reported to stimulate vasodilatation and/or angiogenesis (57). As such, these findings seem to suggest that adiponectin could represent an important link between skeletal muscle tissue perfusion and substrate use.

The presence of adiponectin on the sarcolemmal membrane of the individual muscle fibre implies that adiponectin is bound to adiponectin receptors in muscle tissue for signalling purposes. In that context, the recently cloned adiponectin receptor 1 (expressed abundantly in muscle) and receptor 2 (expressed predominantly in the liver) are likely to play a key role (27). These receptors mediate the elevated glucose uptake and FFA oxidation induced by adiponectin through activation of AMP kinase and peroxisome proliferatoractivated receptor- $\alpha$ ligand activities (27). The latter could potentially stimulate the translocation and/or expression of the various skeletal muscle fatty acid transporters $(9,60)$. As plasma adiponectin concentrations were not affected by either exercise or pharmacological inhibition of adipose tissue lipolysis, we speculated that the effects of adiponectin on muscle metabolism could be mediated at the receptor level. As such, we measured adiponectin 1 and 2 receptor mRNA expression in muscle tissue in both conditions. As expected, adiponectin receptor 1 was more abundantly expressed in muscle tissue than receptor 2 . Prolonged exercise and/or lipolytic inhibition did not change adiponectin receptor 1 mRNA expression (Fig. 5A). Interestingly, adiponectin receptor 2 mRNA content decreased significantly following exercise in the control trial (HFA; Fig. 5B). However, differences in adiponectin receptor 2 mRNA expression between trials did not reach statistical significance $(P=0.08)$. Although these data tend to suggest that there is some negative feedback inhibition of circulating FFA concentrations at the level of the adiponectin receptor, it should be noted that the adiponectin receptor 2 is predominantly expressed in liver and not in muscle tissue. As such, we can only speculate on the physiological relevance to muscle metabolism. It is tempting to hypothesise that more long-term regulation of substrate metabolism is co-regulated by adiponectin production and/or release in adipose tissue, whereas more short-term regulation is also realized at the level of the adiponectin receptor in skeletal muscle tissue and/or the interfibrillar arterioles. More research is warranted to elucidate the physiological role of the adiponectin receptors in various tissues.

In conclusion, prolonged moderate intensity exercise does not affect plasma adiponectin concentrations or skeletal muscle adiponectin receptor 1 and 2 mRNA expression in healthy, lean males. Furthermore, adiponectin concentrations and adiponectin receptor 1 mRNA expression in muscle are not modulated by acute changes in adipose tissue lipolysis, circulating plasma FFA levels and/or whole-body fat oxidation rate. Adiponectin is abundantly expressed in human skeletal muscle tissue, and is located in the sarcolemma of individual muscle fibres and within the endothelial lining of the arterioles. The latter findings imply that there is a regulatory role for adiponectin and/or adiponectin receptors in skeletal muscle metabolism.

\section{Acknowledgements}

We gratefully acknowledge the expert analytical assistance of Jos Stegen and Joan Senden and the enthusiastic support of the subjects who volunteered to participate in these trials. Dr van Loon was supported by a grant from the Netherlands Organisation for Scientific Research (NWO).

\section{References}

1 Scherer PE, Williams S, Fogliano M, Baldini G \& Lodish HF. A novel serum protein similar to $\mathrm{C} 1 \mathrm{q}$, produced exclusively in adipocytes. Journal of Biological Chemistry 1995270 26746-26749.

2 Fruebis J, Tsao TS, Javorschi S, Ebbets-Reed D, Erickson MR, Yen FT, Bihain BE \& Lodish HF. Proteolytic cleavage product of 30-kDa adipocyte complement-related protein increases fatty acid oxidation in muscle and causes weight loss in mice. PNAS 200198 2005-2010.

$3 \mathrm{Hu}$ E, Liang $\mathrm{P} \&$ Spiegelman BM. AdipoQ is a novel adiposespecific gene dysregulated in obesity. Journal of Biological Chemistry $1996 \mathbf{2 7 1} 10697-10703$.

4 Maeda K, Okubo K, Shimomura I, Funahashi T, Matsuzawa Y \& Matsubara K. cDNA cloning and expression of a novel adipose specific collagen-like factor, apM1. Biochemical and Biophysical Research Communications 1996221 286-289.

5 Nakano Y, Tobe T, Choi-Miura NH, Mazda T \& Tomita M. Isolation and characterization of GBP28, a novel gelatin-binding protein purified from human plasma. Journal of Biochemistry $1996 \mathbf{1 2 0}$ 803-812.

6 Arita Y, Kihara S, Ouchi N, Takahashi M, Maeda K, Miyagawa J, Hotta K, Shimomura I, Nakamura T, Miyaoka K, Kuriyama H, Nishida M, Yamashita S, Okubo K, Matsubara K, Muraguchi M, Ohmoto Y, Funahashi T \& Matsuzawa Y. Paradoxical decrease of an adipose-specific protein, adiponectin, in obesity. Biochemical and Biophysical Research Communications $199925779-83$.

7 Hotta K, Funahashi T, Arita Y, Takahashi M, Matsuda M, Okamoto Y, Iwahashi H, Kuriyama H, Ouchi N, Maeda K, Nishida M, Kihara S, Sakai N, Nakajima T, Hasegawa K, Muraguchi M, Ohmoto Y, Nakamura T, Yamashita S, Hanafusa T \& Matsuzawa Y. Plasma concentrations of a novel, adipose-specific protein, adiponectin, in type 2 diabetic patients. Arteriosclerosis, Thrombosis, and Vascular Biology 200020 1595-1599.

8 Yang WS, Lee WJ, Funahashi T, Tanaka S, Matsuzawa Y, Chao CL, Chen CL, Tai TY \& Chuang LM. Weight reduction increases plasma levels of an adipose-derived anti-inflammatory protein, adiponectin. Journal of Clinical Endocrinology and Metabolism $2001863815-3819$.

9 Yamauchi T, Kamon J, Waki H, Terauchi Y, Kubota N, Hara K, Mori Y, Ide T, Murakami K, Tsuboyama-Kasaoka N, Ezaki O, Akanuma Y, Gavrilova O, Vinson C, Reitman ML, Kagechika H, Shudo K, Yoda M, Nakano Y, Tobe K, Nagai R, Kimura S, Tomita M, Froguel P \& Kadowaki T. The fat-derived hormone adiponectin reverses insulin resistance associated with both lipoatrophy and obesity. Nature Medicine 20017 941-946. 
10 Maeda N, Shimomura I, Kishida K, Nishizawa H, Matsuda M, Nagaretani H, Furuyama N, Kondo H, Takahashi M, Arita Y, Komuro R, Ouchi N, Kihara S, Tochino Y, Okutomi K, Horie M, Takeda S, Aoyama T, Funahashi T \& Matsuzawa Y. Diet-induced insulin resistance in mice lacking adiponectin/ACRP30. Nature Medicine $20028731-737$.

11 Mora S \& Pessin JE. An adipocentric view of signaling and intracellular trafficking. Diabetes/Metabolism Research and Reviews $200218345-356$.

12 Goodpaster BH, Kelley DE, Wing RR, Meier A \& Thaete FL. Effects of weight loss on regional fat distribution and insulin sensitivity in obesity. Diabetes $1999 \mathbf{4 8} 839-847$.

13 Goodyear LJ \& Kahn BB. Exercise, glucose transport, and insulin sensitivity. Annual Review of Medicine 199849 235-261.

14 Wojtaszewski JF, Hansen BF, Gade J, Kiens B, Markuns JF, Goodyear LJ \& Richter EA. Insulin signaling and insulin sensitivity after exercise in human skeletal muscle. Diabetes 200049 325-331.

15 Kraemer RR, Aboudehen KS, Carruth AK, Durand RT, Acevedo EO, Hebert EP, Johnson LG \& Castracane VD. Adiponectin responses to continuous and progressively intense intermittent exercise. Medicine and Science in Sports and Exercise 200335 $1320-1325$.

16 Yatagai T, Nishida Y, Nagasaka S, Nakamura T, Tokuyama K, Shindo M, Tanaka H \& Ishibashi S. Relationship between exercise training-induced increase in insulin sensitivity and adiponectinemia in healthy men. Endocrine Journal 200350 233-238.

17 Boudou P, Sobngwi E, Mauvais-Jarvis F, Vexiau P \& Gautier JF. Absence of exercise-induced variations in adiponectin levels despite decreased abdominal adiposity and improved insulin sensitivity in type 2 diabetic men. European Journal of Endocrinology $2003149421-424$

18 Hulver MW, Zheng D, Tanner CJ, Houmard JA, Kraus WE, Slentz CA, Sinha MK, Pories WJ, MacDonald KG \& Dohm GL. Adiponectin is not altered with exercise training despite enhanced insulin action. American Journal of Physiology. Endocrinology and Metabolism 2002283 E861-E865.

19 Kriketos AD, Gan SK, Poynten AM, Furler SM, Chisholm DJ \& Campbell LV. Exercise increases adiponectin levels and insulin sensitivity in humans. Diabetes Care 200427 629-630.

20 Esposito K, Pontillo A, Di Palo C, Giugliano G, Masella M, Marfella R \& Giugliano D. Effect of weight loss and lifestyle changes on vascular inflammatory markers in obese women: a randomized trial. Journal of the American Medical Association 2003289 1799-1804.

21 Ryan AS, Nicklas BJ, Berman DM \& Elahi D. Adiponectin levels do not change with moderate dietary induced weight loss and exercise in obese postmenopausal women. International Journal of Obesity and Related Metabolic Disorders 200327 1066-1071.

22 Yokoyama H, Emoto M, Araki T, Fujiwara S, Motoyama K, Morioka T, Koyama H, Shoji T, Okuno Y \& Nishizawa Y. Effect of aerobic exercise on plasma adiponectin levels and insulin resistance in type 2 diabetes. Diabetes Care 200427 1756-1758.

23 Staiger H, Tschritter O, Kausch C, Lammers R, Stumvoll M \& Haring HU. Human serum adiponectin levels are not under short-term negative control by free fatty acids in vivo. Hormone and Metabolic Research 200234 601-603.

24 Bernstein EL, Koutkia P, Ljungquist K, Breu J, Canavan B \& Grinspoon S. Acute regulation of adiponectin by free fatty acids. Metabolism 200453 790-793.

25 Moitra J, Mason MM, Olive M, Krylov D, Gavrilova O, MarcusSamuels B, Feigenbaum L, Lee E, Aoyama T, Eckhaus M, Reitman ML \& Vinson C. Life without white fat: a transgenic mouse. Genes and Development 199812 3168-3181.

26 Ross SR, Graves RA \& Spiegelman BM. Targeted expression of a toxin gene to adipose tissue: transgenic mice resistant to obesity. Genes and Development 19937 1318-1324.

27 Yamauchi T, Kamon J, Ito Y, Tsuchida A, Yokomizo T, Kita S, Sugiyama T, Miyagishi M, Hara K, Tsunoda M, Murakami K, Ohteki T, Uchida S, Takekawa S, Waki H, Tsuno NH, Shibata Y,
Terauchi Y, Froguel P, Tobe K, Koyasu S, Taira K, Kitamura T, Shimizu T, Nagai R \& Kadowaki T. Cloning of adiponectin receptors that mediate antidiabetic metabolic effects. Nature $2003 \mathbf{4 2 3}$ $762-769$.

28 Kuipers H, Verstappen FT, Keizer HA, Geurten P \& Van Kranenburg G. Variability of aerobic performance in the laboratory and its physiologic correlates. International Journal of Sports Medicine $19856197-201$.

29 Siri WE. The gross composition of the body. Advances Biol Med Physiol $19564238-280$.

30 Murphy RM, Tunstall RJ, Mehan KA, Cameron-Smith D, McKenna MJ, Spriet LL, Hargreaves M \& Snow RJ. Human skeletal muscle creatine transporter mRNA and protein expression in healthy, young males and females. Molecular and Cellular Biochemistry $2003 \mathbf{2 4 4} 151-157$.

31 Altschul SF, Gish W, Miller W, Myers EW \& Lipman DJ. Basic local alignment search tool. Journal of Molecular Biology 1990215 403-410.

32 Peronnet F \& Massicotte D. Table of nonprotein respiratory quotient: an update. Canadian Journal of Sports Science 199116 23-29.

33 Staiger H, Kausch C, Guirguis A, Weisser M, Maerker E, Stumvoll M, Lammers R, Machicao F \& Haring HU. Induction of adiponectin gene expression in human myotubes by an adiponectin-containing HEK293 cell culture supernatant. Diabetologia $200346956-960$.

34 Phillips SA, Ciaraldi TP, Kong AP, Bandukwala R, Aroda V, Carter L, Baxi S, Mudaliar SR \& Henry RR. Modulation of circulating and adipose tissue adiponectin levels by antidiabetic therapy. Diabetes $200352667-674$.

35 Wang Y, Xu A, Knight C, Xu LY \& Cooper GJ. Hydroxylation and glycosylation of the four conserved lysine residues in the collagenous domain of adiponectin. Potential role in the modulation of its insulin-sensitizing activity. Journal of Biological Chemistry $200227719521-19529$

36 Asayama K, Hayashibe H, Dobashi K, Uchida N, Nakane T, Kodera K, Shirahata A \& Taniyama M. Decrease in serum adiponectin level due to obesity and visceral fat accumulation in children. Obesity Research 200311 1072-1079.

37 Hara T, Fujiwara H, Shoji T, Mimura T, Nakao H \& Fujimoto S. Decreased plasma adiponectin levels in young obese males. Journal of Atherosclerosis and Thrombosis $2003 \mathbf{1 0} 234-238$.

38 Kern PA, Di Gregorio GB, Lu T, Rassouli N \& Ranganathan G. Adiponectin expression from human adipose tissue: relation to obesity, insulin resistance, and tumor necrosis factor-alpha expression. Diabetes 200352 1779-1785.

39 Silha JV, Krsek M, Skrha JV, Sucharda P, Nyomba BL \& Murphy LJ. Plasma resistin, adiponectin and leptin levels in lean and obese subjects: correlations with insulin resistance. European Journal of Endocrinology $2003149331-335$.

40 Weiss R, Dufour S, Groszmann A, Petersen K, Dziura J, Taksali SE, Shulman G \& Caprio S. Low adiponectin levels in adolescent obesity: a marker of increased intramyocellular lipid accumulation. Journal of Clinical Endocrinology and Metabolism $2003 \mathbf{8 8} 2014-2018$.

41 Tejero ME, Freeland-Graves JH, Proffitt JM, Peebles KW, Cai G, Cole SA \& Comuzzie AG. Adiponectin but not resistin is associated with insulin resistance-related phenotypes in baboons. Obesity Research $200412871-877$.

42 Comuzzie AG, Funahashi T, Sonnenberg G, Martin LJ, Jacob HJ, Black AE, Maas D, Takahashi M, Kihara S, Tanaka S, Matsuzawa Y, Blangero J, Cohen D \& Kissebah A. The genetic basis of plasma variation in adiponectin, a global endophenotype for obesity and the metabolic syndrome. Journal of Clinical Endocrinology and Metabolism $2001864321-4325$.

43 Weyer C, Funahashi T, Tanaka S, Hotta K, Matsuzawa Y, Pratley RE \& Tataranni PA. Hypoadiponectinemia in obesity and type 2 diabetes: close association with insulin resistance and hyperinsulinemia. Journal of Clinical Endocrinology and Metabolism 200186 1930-1935.

44 Monzillo LU, Hamdy O, Horton ES, Ledbury S, Mullooly C, Jarema C, Porter S, Ovalle K, Moussa A \& Mantzoros CS. Effect 
of lifestyle modification on adipokine levels in obese subjects with insulin resistance. Obesity Research 200311 1048-1054.

45 Smith SA. Central role of the adipocyte in the insulin-sensitising and cardiovascular risk modifying actions of the thiazolidinediones. Biochimie 200385 1219-1230.

46 Bajaj M, Suraamornkul S, Piper P, Hardies LJ, Glass L, Cersosimo E, Pratipanawatr T, Miyazaki Y \& Defronzo RA. Decreased plasma adiponectin concentrations are closely related to hepatic fat content and hepatic insulin resistance in pioglitazone-treated type 2 diabetic patients. Journal of Clinical Endocrinology and Metabolism $200489200-206$.

47 Arner P. The adipocyte in insulin resistance: key molecules and the impact of the thiazolidinediones. Trends in Endocrinology and Metabolism 200314 137-145.

48 Yu JG, Javorschi S, Hevener AL, Kruszynska YT, Norman RA, Sinha M \& Olefsky JM. The effect of thiazolidinediones on plasma adiponectin levels in normal, obese, and type 2 diabetic subjects. Diabetes $2002512968-2974$.

49 Hirose H, Kawai T, Yamamoto Y, Taniyama M, Tomita M, Matsubara K, Okazaki Y, Ishii T, Oguma Y, Takei I \& Saruta T. Effects of pioglitazone on metabolic parameters, body fat distribution, and serum adiponectin levels in Japanese male patients with type 2 diabetes. Metabolism 200251 314-317.

50 Maeda N, Takahashi M, Funahashi T, Kihara S, Nishizawa H, Kishida K, Nagaretani H, Matsuda M, Komuro R, Ouchi N, Kuriyama H, Hotta K, Nakamura T, Shimomura I \& Matsuzawa Y. PPARgamma ligands increase expression and plasma concentrations of adiponectin, an adipose-derived protein. Diabetes 200150 2094-2099.

51 Van Loon LJ, Koopman R, Stegen JH, Wagenmakers AJ, Keizer HA \& Saris WH. Intramyocellular lipids form an important substrate source during moderate intensity exercise in endurance-trained males in a fasted state. Journal of Physiology 2003553 611-625.

52 Van Loon LJ, Greenhaff PL, Constantin-Teodosiu D, Saris WH \& Wagenmakers AJ. The effects of increasing exercise intensity on muscle fuel utilisation in humans. Journal of Physiology 2001 $536295-304$.
53 Matsubara M, Maruoka S \& Katayose S. Decreased plasma adiponectin concentrations in women with dyslipidemia. Journal of Clinical Endocrinology and Metabolism 200287 2764-2769.

54 Tunaru S, Kero J. Schaub A. Wufka C, Blaukat A, Pfeffer K \& Offermanns S. PUMA-G and HM74 are receptors for nicotinic acid and mediate its anti-lipolytic effect. Nature Medicine 20039 352-355.

55 Christie AW, McCormick DK, Emmison N, Kraemer FB, Alberti KG \& Yeaman SJ. Mechanism of anti-lipolytic action of acipimox in isolated rat adipocytes. Diabetologia 199639 45-53.

56 Havel PJ. Update on adipocyte hormones: regulation of energy balance and carbohydrate/lipid metabolism. Diabetes 200453 S143-S151.

57 Goldstein BJ \& Scalia R. Adiponectin: A novel adipokine linking adipocytes and vascular function. Journal of Clinical Endocrinology and Metabolism 200489 2563-2568.

58 Okamoto Y, Arita Y, Nishida M, Muraguchi M, Ouchi N, Takahashi M, Igura $\mathrm{T}$, Inui $\mathrm{Y}$, Kihara $\mathrm{S}$, Nakamura $\mathrm{T}$, Yamashita S, Miyagawa J, Funahashi T \& Matsuzawa Y. An adipocyte-derived plasma protein, adiponectin, adheres to injured vascular walls. Hormone and Metabolic Research 200032 47-50.

59 Chen H, Montagnani M, Funahashi T, Shimomura I \& Quon MJ. Adiponectin stimulates production of nitric oxide in vascular endothelial cells. Journal of Biological Chemistry $2003 \mathbf{2 7 8}$ 45021-45026.

60 Debard C, Laville M, Berbe V, Loizon E, Guillet C, MorioLiondore B, Boirie Y \& Vidal H. Expression of key genes of fatty acid oxidation, including adiponectin receptors, in skeletal muscle of Type 2 diabetic patients. Diabetologia $2004 \mathbf{4 7}$ 917-925.

Received 22 October 2004

Accepted 14 December 2004 